\section{Dusan S. Rajic \\ Researcher \\ University of Belgrade \\ Innovation Center of the Faculty of \\ Technology and Metallurgy}

\title{
LT - Contradiction Matrix
}

Altschuller's Contradiction Matrix and Bartini-Kuznetsov's LT - Table represent two different tools for solving inventive problems based on the same dialectical principle. It starts from the premise that there are contradictions at the root of every problem. Although both tools are designed to make it easier to come up with the Ideal Final Solution (IFS), in practice they often come up with optimal rather than ideal solutions. One of the reasons for this phenomenon can be attributed to the subjectivity of the innovator arising from the logical-descriptive Theory of Inventive Problem Solving (TIPS / rus. TRIZ). The second reason is related to the existence of unidentified laws of nature shown in the LT table of physical quantities. The integration of these two tools yields an effective LT contradiction matrix as a new inventology tool, which does not have the disadvantages of the individual tools from which it arose.

Keywords: TRIZ, LT-contradiction matrix, inventology.

\section{INTRODUCTION}

The ideal final solution (IFS) of any problem is always associated with the maximum utilization of the material and energy resources that reside within the system, in its sub-systems or in the super-system [1]. Finding the right resource is compounded by the contradictions that underlie every problem. They occur when the level of demand is increased compared to the existing system. In doing so, the requirements may be different, hence the diversity of contradictions. There are basically two types of contradictions: technical contradiction (TC) and physical contradiction (PC) [2]. TC occurs between system parameters. When one parameter improves, then the other one inevitably deteriorates. Since the "or-or" principle is represented in this case, the adopted TC solution is based on the optimization of the state of two different parameters [1]. However, according the Theory of Inventive Problem Solving (TIPS/ rus. TRIZ) solution for the TC should be based on the "and-and" principle in order for it to be an IFS. PC occurs only within one element of the system, when it is physically contradictory, i.e. simultaneously warm and cold, or heavy and light, etc. That is why the principle of "andand" is represented in PC, and the obtained solution is based on the idealization of the system, which is closer to the concept of IFS [3]. Since each TC contains one or more PCs, the PCs solution simultaneously leads to the solution of the TC and thus the problem as a whole. So, in search op a solution, one has to go from defining and calculating IFSs, and then through detecting TCs, to solving PCs that are at the core of the problem. By studying patents, Altschuller discovered the basic laws of engineering systems (ES) development and based on them developed a set of tools such as Contradiction Matrix, Algorithm for Inventive Problem Solving (rus. ARIZ), TRIZ standards, and more [4]. Many TRIZ tools

Received: March 2020, Accepted: October 2020

Correspondence to: Dr Dusan Rajic

Innovation Center of the Faculty of Technology and

Metallurgy, Karnegijeva 4, 11000 Belgrade, Serbia

E-mail: drajic@tmf.bg.ac.rs

doi: $10.5937 /$ fme2101095R

(C) Faculty of Mechanical Engineering, Belgrade. All rights reserved indicate that none of them are individually sufficient to solve all problems effectively. The most famous TRIZ tool is the contradiction matrix, which was first revealed 6 decades ago. It includes 39 parameters that describe any ES and 40 principles that are recommended for eliminating TCs and PCs. As science and technology evolve and change on a daily basis, then the original TRIZ contradiction matrix must only be seen as a basis that needs to be supplemented independently in accordance with new solutions contained in scientific and professional publications and patent publications. An innovative contradiction matrix, drawn from procedures taken from the leading fields of technology, can help to find IFS for 21 st century innovative problems. One possible move in this direction is to rely on the work of Bartini who, in addition to design work in the field of aviation, has dealt with the theoretical innovation logic that is essentially the forerunner of TRIZ [5]. He developed a method called "and-and" because of the principle of the physical connection of mutually exclusive properties, and implied "both this and that". This is exactly what Altschuller calls PC. Bartini analyzed the dimensions in an inventive problem using the mathematical apparatus of disaster theory. Bartini informed the Soviet military administration of his mathematical and physical study of the innovation process in 1935, 20 years before the first publication on TRIZ was published $[6,7]$. For a long time, his work was not known to the general public because of the secrecy of the work he did. Therefore, it can be argued that Altschuler and Bartini discovered their dialectical systems in technics independently of one another. It was not until the late 20th century that Bartini's ideas emerged in the works on TRIZ [6-8].

The authors propose to use Bartini's unit system together with TRIZ on a new mathematical basis. However, there are certain weaknesses and inconsistencies in these works, which is why both TRIZ and LT systems can be used individually and only to a limited extent. These papers mainly analyze the innovation process itself, as well as the individual ARIZ steps that are related to the LT system [9-13], but not the contradiction matrix. 
The aim of this paper is to explain possible innovative synergies in finding IFS problems by using the original LT - contradiction matrix in which the TRIZ contradiction matrix is upgraded with the LT system so that the two systems complement each other and simultaneously be used to solve TCs and PCs. This creates the preconditions for a more efficient and much wider application of this new tool in finding IFS to problems of different genesis than it has been the case so far.

\section{COMBINATION OF TRIZ - CONTRADICTION MATRIX AND LT - TABLE}

Innovators must recognize the feature they want to improve as one of the 39 standardized TRIZ parameters that describe any ES. If they are not able to do so, then they consider the most appropriate TRIZ parameter that corresponds to it essentially. They do the same thing when it comes to identifying a defective parameter. However, the application of the similarity criterion leads to a departure from the substance of the problem, thus making reaching an IFS to problems more difficult. In case of applying the Contradiction Matrix, by intersecting the parameters that are being improved with those that deteriorate automatically, it is proposed in the cells of the matrix to use several different TRIZ principles out of a total of 40 defined, the application of which would most probability resolve the TC. This way, over 1200 different TCs that exist in ES can be solved [1]. The TRIZ principles in the cells of the contradiction matrix are listed in the order that most likely leads to the solution of the problem, and they were obtained by the statistical study of patents that had the same TC at the root of their problem. If, nevertheless, no solution is found, then it is suggested to try to find a solution by playing all 40 TRIZ principles [2, 14]. If all the TRIZ principles are completely inapplicable, then the TC should be reformulated so as to achieve some new acceptable concept of a working solution to the problem. These suggestions indirectly confirm the insufficient effectiveness of TRIZ's contradiction matrix. Due to the above facts, certain authors have been trying to create their modified versions of the contradiction matrix, adapting them to various fields of creativity (economics, business, management, pedagogy, chemical technology, etc.) $[1,2,14,15]$. Improvements of the classic contradiction matrix were also attempted by adding or subtracting the number of rows or columns of the matrix, changing the name of the 39 technical parameters, adding new cells to the matrix, or filling in the "empty" matrix cells, adjusting the matrix to the user based on some personal experience, using various mathematical models that would led to the random selection of matrix cells, etc. [16-18]. Although such attempts were made with the best of intentions, they did not contribute to a significant improvement in the effectiveness of the adversarial matrix.

The matrix cannot guarantee the solution of some complex technical problem without its deeper analysis by the innovator. For the users of the matrix, it is therefore recommended to formulate several TCs for a single problem situation, that is, to form a set of recommended principles. Proper implementation of the matrix means that a solution to a technical problem should be sought when the principles are "recommended" more than 3 times during the analysis of a problem situation, and the principle recommended only once should be ignored. In any case, this approach helps to understand and document a number of basic TCs in a system that can be of great importance for problem analysis. One of the main weaknesses of the matrix, but also of TRIZ as a whole, is that it represents a heuristic methodology, based on empirical knowledge and logical-descriptive methodology $[19,20]$. This contributes to increasing the share of subjectivity in finding solutions to problems. However, the ideal solution can be only one, independent of the author trying to define it, and therefore it should be defined with high mathematical precision. The use of space-time (LT) - a system of physical units can reduce subjectivity in the decision-making process. Likewise, using the LT system, it is possible to accurately describe not only the engineering parameters and principles contained in the problem, but also the economic, environmental, biological, chemical and some other parameters [21]. Multiplying the two LT units gives the product a new LT unit that provides "both this and that", which is similar to solving a TC in TRIZ's contradiction matrix. For the mathematical representation of operations with the combination of different physical properties, a comparative system of kinematic quantities according to [5] and an SI system of physical quantities [22] can be compared. It turns out that the interconnectedness of physical quantities does not depend on the system in which they were given [20, 23-25].

The paper [22] proved the existence of 18 of 39 TRIZ parameters as basic LT-units, while the remaining 21 parameters and all 40 TRIZ principles represent state expressions. A detailed description of each individual TRIZ parameter is given in the literature $[16,18,26]$.

Bartini's LT - table can easily find TRIZ parameters classified as basic physical units (1-11, 15-17, 19, 21, 23 and 27). However, other TRIZ parameters, which are classified as condition expressions, cannot be found in the LT - table. They can be reached through mathematical and physical unless you know the value of TRIZ parameters displayed as LT - size, then multiplication or division two known values identify an unknown parameter or TRIZ parameter or TRIZ principle as condition expression. When combining the use of TRIZ's contradiction matrix and LT table, the basic and derived physical units have a convincingly high frequency of occurrence, i.e., extremely large number of repetitions of one LT - unit, while in the expression of state there are more LT - units that have the same frequency of occurrence.

The LT - contradiction matrix (Table 1) was constructed by combining TRIZ contradiction matrix and Bartini-Kuznetsov's LT table. Crossing the two TRIZ parameters yields a cell containing the suggested TRIZ principles presented in the order whose use is most likely to resolve the contradiction. If these two parameters are presented as LT-magnitudes, then their multiplication (or division), or addition (subtraction) of their exponents results in a new LT-magnitude corresponding to the first proposed TRIZ principle, or one whose application would be most likely provide a 
solution to the contradiction. This way the 21 TRIZ parameter and all 40 TRIZ principles representing state expressions can nevertheless be displayed as basic LT units. In the Bartini-Kuznets' LT table, on the other hand, some LT units are known and studied in detail, so they are taken as such in the LT contradiction matrix. This way the 64 parameters were obtained in the LT contradiction matrix. Each of these 64 parameters can be seen as a parameter that is either repaired or broken or represents a solution to the contradiction. If the LT product of the parameter being repaired and the one being corrupted is not among the 64 specified LT parameters $\left(\right.$ eg. $\left.\mathrm{L}^{18} \mathrm{~T}^{-16}\right)$, then this unit $\mathrm{L}^{\mathrm{m}} \mathrm{T}^{\mathrm{n}}$ indicates that the contradiction solution is in a genetic trend whose value is $2(\mathrm{~m}+\mathrm{n}=18-16=2)$ and IFS problems in the form of the required X-resource can be any member of that genetic group. The parameters belonging to the specific genetic group in Table 1 are indicated by a specific color: $-3,-2,-1,0,1,2$ and 3 .

Table 1. The principal part of the LT-contradiction matrix

\begin{tabular}{|c|c|c|c|}
\hline No. & CHARACTERISTICS & $\mathbf{L}^{\mathbf{m}} \mathbf{T}^{\mathbf{n}}$ & $\begin{array}{c}\text { Gen } \\
(\mathbf{m}+\mathbf{n})\end{array}$ \\
\hline 1 & Pressure change & $\mathbf{L}^{2} \mathbf{T}^{-5}$ & \multirow{4}{*}{-3} \\
\hline 2 & Pressure gradient & $\mathbf{L}^{1} \mathbf{T}^{-4}$ & \\
\hline 3 & Change angular acceleration & $\mathbf{L}^{0} \mathbf{T}^{-3}$ & \\
\hline 4 & Bulk density gradient & $\mathbf{L}^{-1} \mathbf{T}^{-2}$ & \\
\hline 5 & Preliminary action & $\mathbf{L}^{7} \mathbf{T}^{-9}$ & \multirow{7}{*}{-2} \\
\hline 6 & Phase transition & $\mathbf{L}^{6} \mathrm{~T}^{-8}$ & \\
\hline 7 & Poynting vector & $\mathbf{L}^{3} \mathbf{T}^{-5}$ & \\
\hline 8 & Pressure & $\mathbf{L}^{2} \mathbf{T}^{-4}$ & \\
\hline 9 & Current density & $\mathbf{L}^{1} \mathbf{T}^{-3}$ & \\
\hline 10 & Angular acceleration & $\mathbf{L}^{0} \mathbf{T}^{-2}$ & \\
\hline 11 & Volume charg density & $\mathbf{L}^{-1} \mathbf{T}^{-1}$ & \\
\hline 12 & Feedback & $\mathbf{L}^{8} \mathbf{T}^{-9}$ & \multirow{11}{*}{-1} \\
\hline 13 & Inert environment & $\mathbf{L}^{7} \mathbf{T}^{-8}$ & \\
\hline 14 & Composite materials & $\mathbf{L}^{6} \mathbf{T}^{-7}$ & \\
\hline 15 & Change of power & $\mathbf{L}^{5} \mathbf{T}^{-6}$ & \\
\hline 16 & Change in force & $\mathbf{L}^{4} \mathbf{T}^{-5}$ & \\
\hline 17 & Surface tension & $\mathbf{L}^{3} \mathbf{T}^{-4}$ & \\
\hline 18 & $\begin{array}{l}\text { Electromagnetic field strength; } \\
\text { Dynamic viscosity }\end{array}$ & $\mathbf{L}^{2} \mathbf{T}^{-3}$ & \\
\hline 19 & $\begin{array}{l}\text { Acceleration; Magnetic } \\
\text { displacement }\end{array}$ & $\mathbf{L}^{1} \mathbf{T}^{-2}$ & \\
\hline 20 & Frequency & $\mathbf{L}^{0} \mathbf{T}^{-1}$ & \\
\hline 21 & Space curvature & $\mathbf{L}^{-1} \mathbf{T}^{0}$ & \\
\hline 22 & Permeability & $\mathbf{L}^{-2} \mathbf{T}^{1}$ & \\
\hline 23 & $\begin{array}{l}\text { Changing the physico-chemical } \\
\text { parameters of the object }\end{array}$ & $\mathbf{L}^{10} \mathbf{T}^{-10}$ & \multirow{12}{*}{$\mathbf{0}$} \\
\hline 24 & Copying & $\mathbf{L}^{9} \mathbf{T}^{-9}$ & \\
\hline 25 & $\begin{array}{l}\text { Intensivity (rate of } \\
\text { maneuverability) }\end{array}$ & $\mathbf{L}^{7} \mathbf{T}^{-7}$ & \\
\hline 26 & $\begin{array}{l}\text { Mobility; Loss of energy a } \\
\text { mobile object }\end{array}$ & $\mathbf{L}^{6} \mathrm{~T}^{-6}$ & \\
\hline 27 & $\begin{array}{l}\text { Power; Stationary object energy } \\
\text { loss }\end{array}$ & $\mathbf{L}^{5} \mathbf{T}^{-5}$ & \\
\hline 28 & $\begin{array}{l}\text { Force; Reliability; Loss of mass } \\
\text { a mobile object }\end{array}$ & $\mathbf{L}^{4} \mathbf{T}^{-4}$ & \\
\hline 29 & Loss of mass a stationary object & $\mathbf{L}^{3} \mathbf{T}^{-3}$ & \\
\hline 30 & $\begin{array}{l}\text { Potential defference; Loss of } \\
\text { information }\end{array}$ & $\mathbf{L}^{2} \mathbf{T}^{-2}$ & \\
\hline 31 & Velocity & $\mathbf{L}^{1} \mathbf{T}^{-1}$ & \\
\hline 32 & $\begin{array}{l}\text { Dimensionless constants; Loss } \\
\text { of time of a stationary object }\end{array}$ & $\mathbf{L}^{0} \mathrm{~T}^{0}$ & \\
\hline 33 & Conductivity & $\mathbf{L}^{-1} \mathbf{T}^{1}$ & \\
\hline 34 & Magnetic permittivity & $\mathbf{L}^{-2} \mathbf{T}^{2}$ & \\
\hline
\end{tabular}

\begin{tabular}{|c|c|c|}
\hline 35 & Partial or excessive actions & $\mathbf{L}^{10} \mathbf{T}^{-9}$ \\
\hline 36 & Antiweight & $\mathbf{L}^{9} \mathbf{T}^{-8}$ \\
\hline 37 & Flexivity (rate of operability) & $\mathbf{L}^{8} \mathbf{T}^{-7}$ \\
\hline 38 & Maneuverabillity & $\mathbf{L}^{7} \mathbf{T}^{-6}$ \\
\hline 39 & $\begin{array}{l}\text { Extencia (Use of energy by } \\
\text { moving object) }\end{array}$ & $\mathbf{L}^{6} \mathbf{T}^{-5}$ \\
\hline 40 & $\begin{array}{l}\text { Temperature; Energy spent by a } \\
\text { stationary object }\end{array}$ & $\mathbf{L}^{5} \mathbf{T}^{-4}$ \\
\hline 41 & $\begin{array}{l}\text { Mass of mobile object; The law } \\
\text { of conservation of impulses }\end{array}$ & $\mathbf{L}^{4} \mathbf{T}^{-3}$ \\
\hline 42 & Weight of stationary object & $\mathbf{L}^{3} \mathbf{T}^{-2}$ \\
\hline 43 & $\begin{array}{l}\text { Length of moving object; } \\
\text { Kinematic viscosity }\end{array}$ & $\mathbf{L}^{2} \mathbf{T}^{-1}$ \\
\hline 44 & Length of stationary object & $\mathbf{L}^{1} \mathbf{T}^{0}$ \\
\hline 45 & \begin{tabular}{|l|} 
Period; Duration of action by \\
stationary object
\end{tabular} & $\mathrm{L}^{0} \mathrm{~T}^{1}$ \\
\hline 46 & Equipotentiality & $\mathrm{L}^{10} \mathrm{~T}^{-8}$ \\
\hline 47 & Application of phase transitions & $\mathbf{L}^{9} \mathbf{T}^{-7}$ \\
\hline 48 & Operabillity & $\mathbf{L}^{8} \mathbf{T}^{-6}$ \\
\hline 49 & Expancia (area spread of power) & $\mathbf{L}^{7} \mathbf{T}^{-5}$ \\
\hline 50 & Linergia & $\mathbf{L}^{6} \mathbf{T}^{-4}$ \\
\hline 51 & Angular momentum; Action & $\mathbf{L}^{5} \mathbf{T}^{-3}$ \\
\hline 52 & $\begin{array}{l}\text { Magnetic Moment; Moment of } \\
\text { mass; Linear transport work }\end{array}$ & $\mathbf{L}^{4} \mathbf{T}^{-2}$ \\
\hline 53 & $\begin{array}{l}\text { Area of moving object; Loss of } \\
\text { substance }\end{array}$ & $\mathbf{L}^{3} \mathbf{T}^{-1}$ \\
\hline 54 & Area of a stationary object & $\mathbf{L}^{2} \mathbf{T}^{0}$ \\
\hline 55 & Distance duration & $\mathbf{L}^{1} \mathbf{T}^{1}$ \\
\hline 56 & Surface time & $\mathbf{L}^{0} \mathbf{T}^{2}$ \\
\hline 57 & Dynamicity & $\mathbf{L}^{9} \mathbf{T}^{-6}$ \\
\hline 58 & $\begin{array}{l}\text { Volupower (3D volumetric } \\
\text { spread of power) }\end{array}$ & $\mathbf{L}^{8} \mathbf{T}^{-5}$ \\
\hline 59 & $\begin{array}{l}\text { Arergation (area spread of } \\
\text { energy) }\end{array}$ & $\mathbf{L}^{7} \mathbf{T}^{-4}$ \\
\hline 60 & Moment of action & $L^{6} T^{-3}$ \\
\hline 61 & $\begin{array}{l}\text { Moment of inertia; Power } \\
\text { transfer }\end{array}$ & $\mathbf{L}^{5} \mathbf{T}^{-2}$ \\
\hline 62 & Volume of a mobile object & $\mathbf{L}^{4} \mathbf{T}^{-1}$ \\
\hline 63 & Volume of stationary object & $\mathbf{L}^{3} \mathbf{T}^{0}$ \\
\hline 64 & Surface velocity & $L^{2} T^{1}$ \\
\hline
\end{tabular}

\section{EXPERIMENTAL PART}

The use of existing shawls, scarves or balaclavas provide protection from the cold, but not respiratory protection of the face from the various types of contaminants that can be found in the air. On the other hand, the use of existing personal respiratory protective equipment on the market is inadequate and unintended for normal living and working conditions, such as going to and from work, using public transport, visiting places of mass gathering, etc., the reason for which people do not even use them in such circumstances, even though they are at an enormous risk of contamination. Consequently, people become massively ill with a series of virulent respiratory infections, especially in winter. With industrial development, there is a significant increase in various types of chronic respiratory diseases such as asthma, allergies, eczema and the like- diseases, which can be caused by various airborne contaminants (sulfur oxides, carbon oxides, heavy metals, polychlorinated biphenyls, various types of biological agents, etc.). Scarf, shawl, and balaclava as clothing units for cold weather that would also have a protective respiratory function for humans would be an ideal solution to the situation described. The problem is there are no such 
products on the market. Therefore, the question is what ideal respiratory protection is necessary for citizens?

Given that the military protective mask is quite expensive and intended to protect against $\mathrm{RBC}$ agents used in war, and impractical to navigate the streets of cities in them, as well as on public transport and in similar places, it is obvious that such an option is not acceptable. There is a similar situation when it comes to various types of masks and half masks developed for members of the special services (police, fire department, etc.). Citizens need a cheap but effective protective mask to wear when traveling around the city. The Epidemiologic Mask (EM) is used for the one-time protection of respiratory organs of medical personnel from contamination by biological agents (BA) transmitted through the air. It is the cheapest personal respiratory protective device on the market. Unlike ordinary EMs, which have 5 - $50 \mu \mathrm{m}$ air openings on them, nano epidemiological masks (NEMs) have 1-2 $\eta \mathrm{m}$ openings on the layer with silver or $\mathrm{TiO}_{2}$ applied. Since the aerosol particles generated by the air contamination are $2.5 \mu \mathrm{m}$ in size, it is clear that classical EMs are not adequate for further consideration. Therefore, the idea is to make a proposal on the basis of NEM to construct a new protective mask that would be targeted at the widest possible population.

All samples of tested NEM are the product of company "9th September" from Gornji Milanovac, Serbia (Figure 1). They consist of three layers made of non-woven textile or polypropylene and one filter layer, which is impregnated with silver nano-particles, and they are disposable.

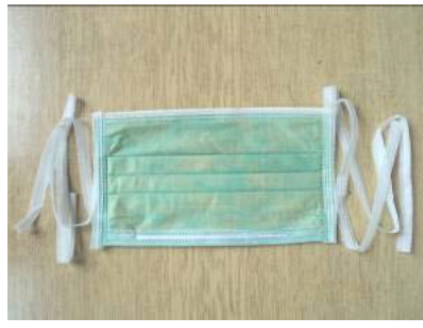

a)

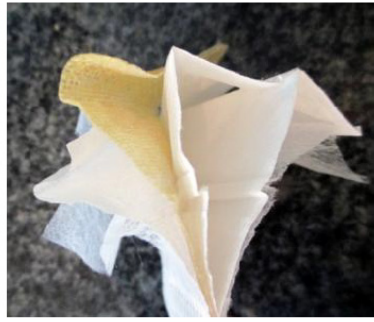

b)
Figure 1. Sample of the NEM with silver nano-particles (a) and a cross-section view of inserted layers of filtering materials in NEM (b).

In the test of NEM samples, the method for testing with $\mathrm{NaCl}$ was defined in the standard [27, 28]. This method is based on the principle of leakage of $\mathrm{NaCl}$ aerosol through a filtering medium, whereby the concentration of this aerosol is measured before and after the test sample by the flame photometry method. Precise determinations are possible in the field of penetration from $0.0001 \%$ to $100 \%$. With $1 \%$ aqueous $\mathrm{NaCl}$ solution, Collison (the manufacturer of BGI, USA) produced a polydispersion solid aerosol concentration $\mathrm{C}_{0}=8 \mathrm{mg} / \mathrm{m}^{3}$ with the following characteristics: particle diameter $\mathrm{dp}=0.02-2.0 \mu \mathrm{m}$, median particles per mass $\mathrm{MMD}=0.60 \mu \mathrm{m}$, median particle by $\mathrm{NMD}=0.03 \mu \mathrm{m}$, geometric deviation $\sigma_{\mathrm{g}}=2.53$. The geometric particle distribution is determined by an electrical particle analyzer EAA-3030 (manufacturer of TSI, USA). The test was carried out in the test chamber at a flow rate of $95 \mathrm{dm}^{3} / \mathrm{min}$, and the test aerosol concentration was measured before and after the filter tested using a flame photometer Type 1100 (manufacturer Moores, Wallisdown LTD., UK).

A test chamber was used to test the effect of the flow of aerosol on the NEM filtration efficiency. The test was carried out by connecting the NEM to the filtering medium, then the aerosol probe was connected, and the test aerosol supply to the test chamber was switched on. Using the flow meter, the desired flow rate of the test aerosol was set to $95 \mathrm{dm}^{3} / \mathrm{min}$, so the test aerosol continuously flowed through the NEM. The aerosol concentration was measured before and after the test sample using a flame photometer. The leakage was measured over $30 \mathrm{~min}$ every $5 \mathrm{~min}$ from the start of the test, as the average response of the instrument for a time interval of $30 \pm 3 \mathrm{~s}$, and the read data was recorded. At the same time, the gauge also measured the resistance of the filtering medium through the flow of aerosols and the data is recorded. The manometer was connected to the space below the medium in the dispenser of the filter medium with one copy and the other open to the atmosphere.

The results obtained by the experimental tests were grouped according to the series according to the performed tests. The basic statistical parameters series of results were obtained by their processing using the statistical software package IBM SPSS Statistics Data Editor, version 20. The statistical significance in the processing of the results was defined at a probability level of 0.05 .

\section{RESULTS AND DISCUSSION}

From the standpoint of ideality (Table 2), it has been found that for NEM the main problem is inhalation resistance at a flow rate of $95 \mathrm{dm}^{3} / \mathrm{min}$. For NEM, it is IFS $=47.8 \%$. Since this is a quantitative calculation, this means that a real budget is enabled. This is important because all the necessary values are approximately familiar: the choice of parameters $\mathrm{Pi}$, their current values, the relative importance of $\mathrm{Ki}$, and the possible interval values (Pmin, Pmax) reflect knowledge of user's needs and saturation coefficients on the market, while $\mathrm{Li}$ available knowledge on market offer of the product. This information is essential for the implementation of consulting or project services. This analysis takes into account mathematical non-linearity. In addition, it also takes into account subjective non-linearity over a parameter interval, ponder, and a market saturation coefficient. It is possible to identify prohibited variants of modification engineering of devices where the improvement of one of the parameters, even if it is very significant, makes at least one IFS parameter equal to zero, which makes this modification useless. It also allows the identification of unreasonable variants of modification leading to the passage of some parameters to a zone that represents a meaningless resource consumption, as this does not increase IFS.

Even though NEM meets the most stringent criteria prescribed by the standard for the FFP3 half-mask category, from the standpoint of ideality it is well below the desired level (IFS $=47.8 \%$ ) (Table 2). Standards are set for the level of quality that can be met. When new materials and technologies are conquered, then these standards are tightened, thereby moving toward ideality. 
Since inhalation resistance is a major factor in reducing comfort when using NEM, then one should think in the direction of how it can be reduced. Obviously, one way to reduce the resistance is to reduce the number of NEM layers. If this is done, then the mass of the NEM will decrease.

Table 3 contains parameter no. 42 - Weight of stationary object $\left(\mathrm{L}^{3} \mathrm{~T}^{-2}\right)$ which has to be reduced. If this happens, then the permeability of the NEM will deteriorate.

Table 2. The achieved degree of ideality in the construction of NEM

\begin{tabular}{|c|c|c|c|c|}
\hline Parameters & $\begin{array}{c}\text { Leakage } \\
\text { through } \\
\text { the } \\
\text { filtering } \\
\text { medium }\end{array}$ & $\begin{array}{c}\text { Inhalation } \\
\text { resistence } \\
(\mathrm{Pa}) \text { at the } \\
\text { flow of 95 } \\
\mathrm{dm}^{3} / \mathrm{min}\end{array}$ & $\begin{array}{c}\text { Comfort } \\
\text { (points) }\end{array}$ & $\begin{array}{c}\text { IFS } \\
(\%)\end{array}$ \\
\hline Pmin-Pmax & $\begin{array}{c}0.8403- \\
0.9283\end{array}$ & $125-145$ & $1-10$ & \\
\hline $\mathrm{P}$ & 0.91652 & 129 & 9 & \\
\hline $\mathrm{K}$ & 0.9 & 0.9 & 0.8 & \\
\hline $\mathrm{L}$ & 0.8 & 0.9 & 0.8 & \\
\hline $\mathrm{S}, \%$ & 59.6 & 16.4 & 68.6 & 47.8 \\
\hline $\mathrm{R}, \%$ & 26 & 53.8 & 20.2 & $\sum 100$ \\
\hline
\end{tabular}

Table 3, under number 22, lists Permeability $\left(\mathrm{L}^{-2} \mathrm{~T}^{1}\right)$. Multiplying these quantities yields $\mathrm{L}^{1} \mathrm{~T}^{-1}$, i.e. velocity.

Table 3. The part of LT-innovation matrix of contradictions used for case analysis

\begin{tabular}{|c|c|c|c|c|c|c|}
\hline \multicolumn{3}{|c|}{ CHARACTERISTICS } & \multicolumn{4}{|c|}{ Worsening Feature } \\
\hline & & & $\mathrm{L}^{\mathrm{m}} \mathrm{T}^{\mathrm{n}}$ & Gen & 22 & 45 \\
\hline \multirow{5}{*}{ 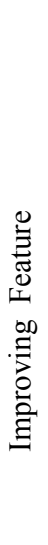 } & 22 & Permeability & $\mathrm{L}^{-2} \mathrm{~T}^{1}$ & -1 & $\mathrm{~L}^{-4} \mathrm{~T}^{2}$ & $\mathrm{~L}^{-2} \mathrm{~T}^{2}$ \\
\hline & 31 & Velocity & $\mathrm{L}^{1} \mathrm{~T}^{-1}$ & 0 & $\mathrm{~L}^{-1} \mathrm{~T}^{0}$ & \\
\hline & 42 & $\begin{array}{l}\text { Weight of } \\
\text { stationary } \\
\text { object }\end{array}$ & $\mathrm{L}^{3} \mathrm{~T}^{-2}$ & \multirow[b]{2}{*}{1} & $\mathrm{~L}^{\mathrm{I}} \mathrm{T}^{-1}$ & $\mathrm{~L}^{3} \mathrm{~T}^{-1}$ \\
\hline & 45 & $\begin{array}{c}\text { Period; } \\
\text { Duration of } \\
\text { action by } \\
\text { stationary } \\
\text { object }\end{array}$ & $\mathrm{L}^{0} \mathrm{~T}^{1}$ & & $\mathrm{~L}^{-2} \mathrm{~T}^{2}$ & $\mathrm{~L}^{0} \mathrm{~T}^{2}$ \\
\hline & 53 & $\begin{array}{c}\text { Area of } \\
\text { moving } \\
\text { object; Loss } \\
\text { of substance }\end{array}$ & $\mathrm{L}^{3} \mathrm{~T}^{-1}$ & 2 & $\mathrm{~L}^{1} \mathrm{~T}^{0}$ & $\mathrm{~L}^{3} \mathrm{~T}^{0}$ \\
\hline
\end{tabular}

The dynamics of aerosol filtration by filtration media is a consequence of changes that occur in the filtration material itself, that is, changes in its structure during it exploitation. These changes occur most often due to the deposition of particles on the fibers of the filter material, when the separated particles are not distributed properly over the fiber surface but form chain clusters, thus increasing the thickness of the barrier (fiber + precipitated particles) and reducing porosity. This process increases the efficiency of the filter medium with a slight increase in resistance. The longer the filtration process, or the higher the particulate concentrations of the aerosol dispersion system, the faster the more homogeneous layer of particles is formed, which, depending on size, results in a greater or lesser increase in the flow resistance of the aerosol. If the aerosol and flow are constant characteristics, ideally, the filtration efficiency and resistance change are directly proportional to the filtration time. According to this setting, the quality characteristics of a particular filter material can be determined by testing the dynamics of aerosol filtration by filter media, i.e. by testing the filtration efficiency at different flows, as well as by simultaneously testing the filtering efficiency and changing the resistance of the filtering material depending on the filtration time at different flows. The filtration rate can be increased if the exhalation valve is installed in the NEM or reduced to 3 or 2 instead of 4 layers. The installation of the exhalation valve reduces the resistance to the exhalation of the air, reduces the wetting of the NEM surface that touches the face due to saliva dripping, facilitates the ejection of $\mathrm{CO}_{2}$, heat and moisture generated by breathing.

If the NEM mass decreases, then the protection time will decrease too. This can be represented by using units from the LT contradiction matrix (Table 3). The mass of a stationary object is being fixed $\left(\mathrm{L}^{3} \mathrm{~T}^{-2}\right)$, thereby the protection period or parameter no. $45\left(\mathrm{~L}^{0} \mathrm{~T}^{1}\right)$ deteriorates. Multiplying these two units gives the parameter no. $53\left(\mathrm{~L}^{3} \mathrm{~T}^{-1}\right)$, that is, the surface of a mobile object is reduced or the substance is lost. How can this loss be compensated for? If one of the protective layers is pleated, then its surface is greatly enlarged. Since the mass should be reduced, this means that one layer of NEM should be discarded, and one of the layers should be pleated as a form of compensation. The NEM salt layer could be impregnated with a layer of silver or $\mathrm{TiO}_{2}$. Textile-applied $\mathrm{TiO}_{2}$ nanoparticles may affect its hydrophobicity / hydrophilicity, antibacterial properties, and crease resistance [29-31]. In contact with sunlight, they exhibit the decontamination properties of highly toxic substances. This means that NEM can be constructed as a part of everyday wear in winter conditions (scarf, shawl or balaclava), and in the case of protection against highly toxic substances, bacteria and viruses on a chemical basis it will effectively protect the wearer. $\mathrm{TiO}_{2}$ nanoparticles have low cost and low toxicity. They have been known for many years in the cosmetics industry as a major active ingredient in sunscreen creams and lotions. There are numerous studies showing that micro- and nano-particles of $\mathrm{TiO}_{2}$ are not mutagenic and genotoxic to humans.

The respiratory protection mechanism of such a respiratory protective device is based on the principle of purification of contaminated air, which is inhaled through the filtration medium, while isolating a part of the face from contact with the outside air, reducing the concentration of the contaminant from the environment and overcoming the corresponding respiratory resistance. In order to achieve the ideal model of a protective scarf, shawl or balaclava (maximum protection efficiency with minimal inhalation resistance), there is a constantly search for improvement of the characteristics of the materials used to make the filter that is built into it. The filter medium may be based on a fibrous or granular material (glass, cotton or plastic material, where fibers may be entangled in a paper structure). The use of fibrous filter media in the form of paper is based on its porosity. Such fibrous filter materials consist of a maze 
of fibers of different diameters equal to or less than three times the diameter of the contaminating particles. It is also necessary to keep the fiber diameter small relative to the distances between the fibers. Good filter materials have low aerosol movement resistance and high filtering capacity without high pressure drop (Figure 3). Such are e.g. High Efficiency Particular Air (HEPA) filters that can be made of paper or cellulose (disposable), stopping particles up to $0.3 \mu \mathrm{m}$ in size, or Polytetrafluoroethylene (PTFE) fluoroplastic fibers retaining particles up to $0.06 \mu \mathrm{m}$ (reusable). With the development of nanotechnology, the characteristics of the filtering materials have been raised to a very high level, so that they have the ability to filter micron and submicron particles, as well as gaseous contaminants. Such a filter material typically contains fibers of several types of material, usually cellulose or glass fibers. Plastic fibers are sometimes added to the filter material at a concentration below $7 \%$ to improve acid resistance. Also, small amounts of admixtures are added to the fiberglass to improve the characteristics of the filter material, such as resistance to mold, water, stretching, etc. Thus, $\mathrm{TiO}_{2}$ or $\mathrm{Ag}$ nanoparticles can be deposited on textile, woolen or other substrates which prevent the penetration of the largest particles from the air, but at the same time exhibit antibacterial and antiviral capacity [28]. Volatile Organic Compounds (VOC) filters are used to prevent the penetration of easily volatile compounds that can be found in the air. They are made from fabric onto which spherical beads of activated carbon are applied.

Installing one or two exhalation valves reduces the resistance when using NEM. The pleating of the inner layer increases the active surface of the filtration. The NEM outer layer is impregnated with $\mathrm{Ag}$ or $\mathrm{TiO}_{2}$. nano particles. An internal color-changing indicator is installed on the NEM inner layer in case of saturation with NEM contaminants. Such NEM is placed in a pocket on a scarf (headscarf or balaclava) or fastened with a Velcro strap and, if necessary, placed in a protective position (Figure 2). The proposed NEM design allows washing in case of saturation with contaminants, without reducing the filtering efficiency thereafter. When using scarves, shawls and balaclavas to protect the respiratory organs (small, medium, or large), care must be taken that they are first thing applied to the respiratory organs (mouth and nose) is a suitable protective filter or NEM, depending on size of the face of the user, that is, the range of anthropometric dimensions of the user's head. The metal strap from the filter is then applied to the upper part of the wearer's nose so that the NEM is tightly sealed, and then resumed by wrapping the scarf around the neck and head, just like using a regular scarf.

The proposed principled solution completely solves the problem of cheap, long-lasting, effective protection and high physiological suitability of the personal protection agent in case of application of BAg and contamination with solid aerosols. Based on the proposed principled solution of different garments with built-in NEM, a prototype of the garment can be made. It must be tested experimentally to verify its effectiveness in laboratory and field conditions, and then the IFS to problems of that newly proposed personal respiratory protective device intended for the population can be measured and calculated. Thus, using the LT - contradiction matrix, a new principled design solution of the personal respiratory protective device intended for the population closer to the concept of ideality in relation to other available means on the market was proposed.

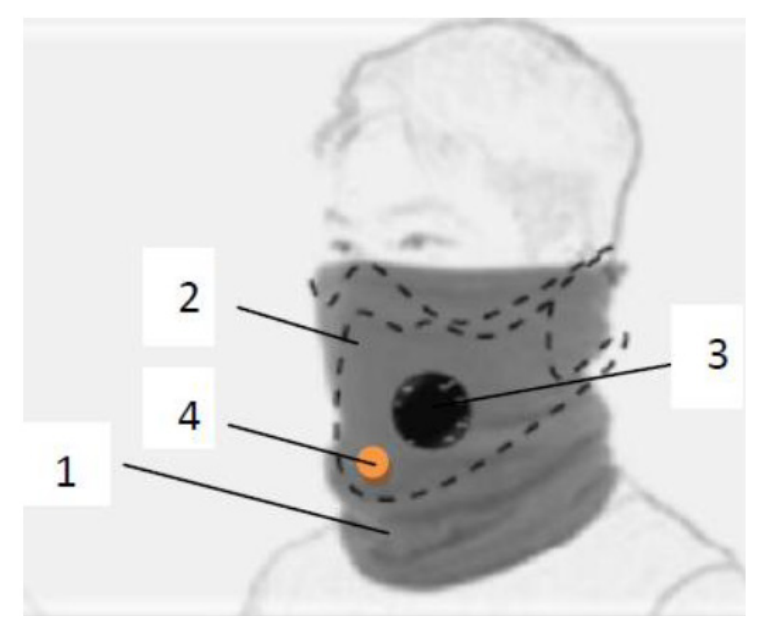

Figure 2. Prototype of a scarf with inserted NEM: 1- scarf; 2-NEM; 3-exhalation vault; 4- contamination indicator

\section{CONCLUSION}

Subjectivity when using the TRIZ contradiction matrix and the LT system's excessively high accuracy, have been successfully reduced or completely eliminated by using the LT contradiction matrix as a new tool of inventology. The LT contradiction matrix has 64 parameters that are repaired, malfunctioned, or a solution to the contradiction problem that arises when one wants to improve a feature of an engineering system. Its implementation has synergistically increased the capacity to find IFS to different problems arising from 3210 possible contradictions.

The application of the LT contradiction matrix was successfully demonstrated in the case study of the development of a personal respiratory protective device for the population. As the effects of protection and physiological suitability are key parameters that these agents need to satisfy, leakage tests of $\mathrm{NaCl}$ aerosol as a biological agent simulator were performed for their reliable assessment. An internal aerosol leakage test found that NEM met the standard criteria for the FFP3 half-mask class. However, the criteria met by the standards are below $50 \%$ relative to ideal.

This shows that this mask needs improvement. NEM structural improvements were proposed based on the results obtained using the LT contradiction matrix. They should aim to reduce inhalation resistance and increase filtration efficiency. This can be achieved by installing a smaller number of protective layers made of higher quality materials (pleated, impregnated with $\mathrm{Ag}$ or $\mathrm{TiO}_{2}$ nanoparticles and of activated carbon) from which NEM protective layers are made, in order to achieve a lower packing density and increase the filling capacity, ie less leakage of contaminant and less resistance to inhalation of air. The installation of an exhalation valve can further reduce breathing resistance and thus increase the comfort of wearing such a NEM. 
Incorporating NEMs into cold-proofing products such as scarves, shawls, and balaclavas will achieve a more ideal solution to the problem of effective respiratory protection of the population in winter than existing solutions.

\section{ACKNOWLWDGEMENTS}

The Ministry of Education, Science and Technological Development of the Republic of Serbia (Contract No. 451-03-68/2020-14/200135) supported this work.

\section{REFERENCES}

[1] Rajic, D.: Eco-inventology, Author's edition, Belgrade, 2019. (In Serbian: Rajić, D.: Ekoinventologija, Autorsko izdanje, Beograd, 2019).

[2] Rajic, D., Kamberovic, Z. and Zakula, B.: Creative Engineering, IC TMF, Belgrade, 2016. (In Serbian: Rajić, D., Kamberović, Ž. and Žakula, B.: Kreativni inžinjering, IC TMF, Beograd, 2016).

[3] Rajic, D., Ivankovic, N. and Karkalic, R.: Defining the Ideality of the Protective Masks by the Mathematical Modeling Method, FME Transactions, Vol. 47, No. 3, pp. 496-501, 2019.

[4] Rajic, S. D.: Inventive Level as a Basic for the Assessment of Scientific Contribution of Inventors, FME Transactions, Vol. 47, No. 1, pp.76-82, 2019.

[5] Bartini, R.: Some relationships between physical quantities. Dokl. Akad. Nauk SSSR, Ser. Fiz. 163, 4, pp. 861-864, 1965. (in Russian: Бартини, P.: Некоторые соотношения между физическими константами./ Доклады Академии наук СССР. Том 163, № 4, С 861-864, 1965).

[6] Bushuev, A. B. and Petrov, V. A.: Simulation modeling of control systems in the LT basis, Proceedings of the Eighth All-Russian Scientific and Practical Conference on Simulation Modeling and its Application in Science and Industry "Simulation. Theory and Practice "(IMMOD-2017) section 1., October 18-20.10.2017, St. Petersburg, pp. 88-93. (In Russian: Бушуев А.Б., Петров B.A.: Имитационное моделирование систем управления в LT-базисе. Труды Восьмой Всероссийской научно-практической конференции "Имитационное моделирование. Теория и практика" (ИММОД-2017) (СПб, 1820октября 2017г.). 2017. С. 88-93).

[7] Bushuev, A. B.: Search for quantitative estimates of resources in the Bartini basis / Collection of reports of the VII international conference "TRIZ: application practice and development problems", 2015, Moscow, pp. 221-225. (In Russian: Бушуев А.Б: Поиск количественных оценок ресурсов в базисе Бартини. Сборник докладов международной конференции "ТРИЗ: практика применения и проблемы развития" (Москва, 20-21ноября 2015г.). 2015. С. 221225.).

[8] Bushuev, A. B.: High-speed innovation in the framework of the theory of disasters and TRIZ,
"TRIZ in development" / Collection of research papers, TRIZ Developers Summit Library. Issue 9., 2017, St. Petersburg, Russia, pp. 41 - 54. (In Russian: Бушуев А.Б.: Скоростная инновация в рамках теории катастроф и ТРИЗ. ТРИЗ в развитии: материаль научно-практической конференции (СПб, 20-22июня 2017г.). Библиотека Саммита разработчиков ТРИЗ. 2017. № 9. С. 41-54.).

[9] Bushuev, A.: Technical Contradiction Control on Invention Problem, The TRIZ Journal, Decembar, 2004. [Online] Avaible at https:/ / triz - journal.com technical - contradiction - control - invention problem / (28.01.2020).

[10]Bushuev, A.: The Dynamic Substance - Field Analisys in ARIZ, The TRIZ Journal, December 2005. [Online] Avaible at https: // triz-journal.com /dynamic - substance - field - analysis - ariz / (28.01.2020).

[11]Bushuev, A.: The Search Substance-Field, The TRIZ Journal, June 2006. [Online] Avaible at https:/ /triz-journal.com/search-substance-field/ (28.01.2020.)

[12]Bushuev, A.: X-element: Search, Capture, Tracking, Proceedings of TRIZ - Fest 2006, 1318.10.2006., pp. 310-317.

[13] Wei Z., Li Q., Wang D. and Tian Y.: The Application of LT-Table in TRIZ Contradiction Resolving Process. In: Tan R., Cao G., León N. (Eds) Growth and Development of ComputerAided Innovation. IFIP Advances in Information and Communication Technology, Vol 304, pp. 266-275, Springer, Berlin, Heidelberg, 2009.

[14]Rajic, D.: Creative Ecology, Author's edition, Belgrade, 2016. (In Serbian: Rajić, D.: Kreativna ekologija, Autorsko izdanje, Beograd, 2016).

[15] Rajic, D.: Inventology, Author's edition, Belgrade, 2017. (In Serbian: Rajić, D.: Inventologija, Autorsko izdanje, Beograd, 2017).

[16]Coelho, D. A.: Matching TRIZ engineering parameters to human factors issues in manufacturing, Wseas Transactions on Business and Economics, Vol. 6, No. 11, pp. 547-556, 2009.

[17] Cherifi, A., Dubois, M., Gardoni, M. and Tairi, A.: Methodology for innovative eco-design based on TRIZ, Int. J. Interact. Des. Manuf., No. 9, pp.167$175,2015$.

[18]Mann, D. and Dewwulf, S.: Updating the Contradiction Matrix, TRIZCON2003: 5th Annual International Conference of Altschuller Institute for TRIZ Studies, held at Philadelphia, PA, USA, 1618.03.2003. [Online] Avaible at https://www.osaka - gu.ac.jp /php/ nakagawa / TRIZ/ eTRIZ /epapers/ e2003Papers/eMannDeWulf0303/ eMannMatrix 030316. html / (28.01.2020).

[19]Rajic, D.: Contribution of eco-inventology to concept of sustainable development, In book: Innovation as an Initiator of the Development "Innovations - Development Prospects", International Thematic Monograph - Thematic Proceedings, 
Publisher: University Business Academy in Novi Sad, Faculty of Applied Management, Economy and Finance, Belgrade, 05.12.2019, pp. 259-276.

[20] Rajic, D.: Innovative synergism as a result of TRIZ and LT-system synthesis, In book: Innovation as an Initiator of the Development "Innovations Development Prospects", International Thematic Monograph - Thematic Proceedings, Publisher: University Business Academy in Novi Sad, Faculty of Applied Management, Economy and Finance, Belgrade, 05.12.2019, pp. 226-242.

[21] Bolshakov, B. E., Petrov, A. E.: Algoritm of Multidimenzional Space and Time Values Interrelation the in System of LT Dimension Coordinates by B. Brown, R. O. Bartini, P. G. Kuznetsov, Journal of Engineering and Applied Sciences 12 (Special Issues 3), pp. 6620-6627, 2017.

[22] Rajic, D.: Compatibility between TRIZ - contradiction matrix and LT-unit system, FME Transactions, Vol. 48, No. 2, pp. 460-467, 2020.

[23] Chujev, A. S.: Physical picture of the world in the dimension "length-time". Series Informatization of Russia on the threshold of the XXI century. - M., SINTEG, 1999 (In Russian: Чуев, А. С.: Физическая картина мира в размерности "длинавремя", М., СИНТЕГ, 1999 г.), [Online] Avaible at http://www.chuev.narod.ru / (05.01.2020).

[24]Chujev, A. S.: On existing and theoretically possible force laws found in a system of physical quantities, 2003. (In Russian: Чуев, А. C.: О необходимости раздельного представления систем механических (гравитационных) и электромагнитных физических величин, 2003). [Online] Avaible at http: // www. sciteclibrary.ru/ rus/catalog/pages /5811.html / (05.01.2020).

[25] Chujev, A. S.: About a multilevel system of physical quantities expressing the laws of nature, in particular, the structure and relationships of electromagnetic quantities, 2004. (In Russian: Чуев, А. С.: О многоуровневой системе физических величин, выражающей законы природы, в частности, структуру и взаимосвязи электромагнитных величин, 2004). [Online] Avaible at http:/ /www.sciteclibrary.ru/ rus/catalog/pages/7335.html/ (05.01.2020).

[26] Domb, E.: The 39 Features of Altshuller's Contradiction Matrix, The TRIZ Journal, Nov. 1998. [Online] Avaible at https://trizjournal.com/39-features-altshullers-contradiction matrix / (14.01.2020).

[27] Ivanković, N., Rajić, D., Karkalić, R., Jovanović, D., Radovanović, Ž., Stupar, S. and Janković, D.:
Influence of the aerosol flow and exposure time on the structural changes in the filtering half masks material, J. Serb. Chem. Soc., Vol. 83, No. 4, pp. 463-471, 2018.

[28]Rajic, D. and Ivankovic, N.: Contributions of impregnated silver nanoparticles to ideality increase of filtration material in human respiratory protection, Material Protection, Vol. 60, No. 4, pp. 360-368, 2019.

[29] Bauk, S., Vitorovic-Todorovic, M., Mazanec, K., Senic, Z., Pajic, N., Rajic, D.: Decomposition of organic dyes and CWA simulants by nano-TiO2 treated standard military textiles, Proceedings of the 5th International Conference on Defensive Technologies, Belgrade, 18-19.09. 2012, pp. 693-697.

[30] Senic, Z., Bauk, S., Simic, D., VitorovicTodorovic, M., Markovic, T., Radojkovic, A. and Rajic, D.: The Preliminary Comparative Analysis of Different Routes for $\mathrm{TiO} 2$ Nanoparticles Synthesis and Their Deposition on Textiles. The Methyl-Orange Degradation and VX Detoxication Study. Digest Journal of Nanomaterials and Biostructures, No. 8, pp. 711-719, 2013.

[31] Senic, Z., Bauk, S., Vitorovic-Todorovic, M., Pajic, N., Samolov, A. and Rajic, D.: Application of $\mathrm{TiO}_{2}$ Nanoparticles for Obtaining Self - Decontaminating Smart Textiles, Scientific Technical Review, Vol. 61, No. 3-4, pp. 63-72, 2011.

\section{ЛТ - МАТРИЦА КОНТРАДИКТОРНОСТИ}

\section{Д. Рајић}

Алтшулерова матрица контрадикторности и Бартини-Кузњецова ЛТ-табела представљају две различите алатке за решавање инвентивних проблема на истом дијалектичком принципу. Он полази од премисе да се у основи сваког проблема налазе контрадикције. Иако су обе алатке осмишљене са циљем да се олакша долазак до идеалног коначног решења (ИКР) проблема, у пракси се често добијају оптимална, а не идеална решења. Један од разлога за ту појаву може се приписати субјективности иноватора која проистиче из логичко-описне Теорије решавања инвентивних задатака (ТРИЗ). Други разлог је везан за постојање неидентификованих закона природе приказаних у ЛТ-табели физичких величина. Интеграцијом ове две алатке добијена је ефикасна ЛТ-матрица контрадикторности као нова алатка инвентологије, која нема недостатке појединачних алатки из којих је настала. 